\title{
SECURITY MEASURES ORIENTED TOWARD THE PERPETRATORS OF VIOLENT CRIMES IN THE REPUBLIKA SRPSKA
}

Žana Vrućinić ${ }^{1}$

Faculty of Security Studies, University of Banja Luka

Dragana Vasiljević

Faculty of Security Studies, University of Banja Luka

Review Paper

\begin{tabular}{|l|l|l|}
\hline DOI 10.7251/ZBKEN1901027V & COBISS.RS-ID 8274200 & UDK 343.13:343.211.3]:351.74(497.6PC) \\
\hline
\end{tabular}

\begin{abstract}
Violence, as a destructive form of behavior, has always been present in interactive relationships. Legislation defines certain forms of its manifestation as offenses and provides for appropriate criminal sanctions. The Criminal Code of Republika Srpska retained the solutions from the Law on Amendments and Supplements to the 2013 Criminal Code of Republika Srpska, when certain novelties were introduced regarding criminal legal responses to violent crimes. This paper addresses personality traits in individuals who commit violent crimes, as well as security measures oriented toward the perpetrators of violent crimes in the criminal legislation of Republika Srpska.
\end{abstract}

Keywords: violence, offense, perpetrator, security measures.

\section{GENERAL REMARKS ON VIOLENT CRIMES AND SECURITY MEASURES}

Violence, be it organized or random, continuous or occasional, intense or uncontrollable, always harms or destroys the object at which it is aimed or is attempting to do so (Bartol \& Bartol, 2005: 241). It is a phenomenon difficult to explain. The difficulties in defining crimes of violence arise from the fact that they can be comprehensively understood, thus viewpoints that every crime represents a form of violence may be accepted. Levi and Maguire (Levi \& Maguire, 2000) argue that it is a "slippery" term covering a very wide range of activities ranging from terrorist attacks, gangs, street robberies to domestic violence between spouses, which again may range from murder and rape to insults causing psychological injuries (Levi \& Magiure, 2002: 796). It

\footnotetext{
${ }^{1}$ Corresponding author: Žana Vrućinić, Assistant Professor, Faculty of Security Studies, University of Banja Luka. E-mail: zana.vrucinic@fbn.unibl.org
} 
is about forms of crimes using assaults and threats to the victim to achieve a goal (Marković, 2007: 203-204). Man is distinguished here as a unique being, and the malignant aggression that occurs in him/her is not phylogenetically programed. Only man can torture and murder his/her own kind, while feeling pleasure at the same time (Kovačević, 2006: 14).

Criminal legal responses to the undertaking of violent actions are focused on two directions. Certain human behaviors are qualified as offenses. In this way, the legislature provides criminal legal protection for certain legal goods. ${ }^{2}$ Violent crimes toward which security measures are oriented are usually contained in the chapter entitled Crimes against Marriage and Family. This type of violence, also referred to as "violence among partners" or "violence among spouses", means any insult, intimidation, sexual insult, as well as any other act that may result in a bodily injury or death of a family member or someone living in the same household (Wallace \& Seymour, 2007: 299). Some researchers (Johnson, 1995) indicate different forms of intimate partner violence and/ or different types of aggressors. Studies conducted on clinical samples (respondents from safe houses and respondents who sought medical assistance or reported violence) describe intimate partner violence as intimate terrorism. In such cases, violent men are far more powerful than female perpetrators, aggression is largely unilateral (except in the case of self-defense), it is more frequent and escalates suddenly. On the other hand, studies addressing intimate partner violence in a sample of the general population mainly describe violence as mutual. This form of aggression is less severe, less frequent, does not escalate over time, and it usually involves both partners using physical force during the conflict.

The perpetrators of mutual (domestic) violence commit less severe forms of physical violence toward their spouses/partners and do not commit crimes outside the family. Basically, these individuals do not differ from nonviolent individuals with disturbed marital relationships. On the contrary, the perpetrators of intimate terrorism (antisocial domestic violence) (HoltzworthMunroe \& Stuart, 1994) are involved in serious physical, sexual and psychological abuse of their partners. They are characterized by negative attitudes toward women, alcohol abuse, drug abuse, in other words, by a wide range of socially undesirable behaviors.

The criminalization of such behaviors represents a legal framework for another form of criminal legal response - criminal sanctions. In addition to the victim, the judiciary should bear these offences in mind as well, because it is in the commission of these offences that the perpetrator's (abuser's) personality

\footnotetext{
${ }^{2}$ Violent crimes are not usually systematized in a way to be grouped only in one chapter of the Criminal Code. On the contrary, they are interlinked throughout the entire Special Section of the Criminal Code (e.g., crimes against life and body, offences against sexual integrity, public order offences, crimes against marriage and family, crimes against the freedom and rights of citizens, crimes against property, and so on). In this regard, it may be noted that these offences constitute the largest number of the total crimes committed. For more details, see: Statistical Yearbook of Republika Srpska. Retrieved August 21, 2018, from http://www.rzs.rs.ba/front/category/8/.
} 
traits come to the fore, which is supported by the introduction of new security measures in our criminal legislation. These supplementary criminal sanctions enhance the preventive effect of punishment. In this regard, research findings and practical experience have demonstrated that the suppression of criminality of certain criminological categories cannot be accomplished through the application of punishment alone (Drakić, 2005: 123). The legislature is very explicit here: within the framework of the general purpose of the criminal sanctions, the purpose of security measures is to eliminate situations or conditions that might influence the perpetrator to perpetrate offences in the future (Article 71).

Prior to the adoption of the Law on Amendments to the Criminal Code of Republika Srpska ${ }^{3}$, the security measures oriented toward perpetrators of violent crimes were not encompassed by the provisions. ${ }^{4}$ However, within the reform of misdemeanor legislation, the Law on Amendments to the Law on Protection from Domestic Violence provided for appropriate protection measures in Article 23(a): the removal of the perpetrator from the apartment, house, or other dwelling, the measure prohibiting the perpetrator from approaching the victim and from harassing and stalking the victim of domestic violence, mandatory psychosocial treatment, and mandatory addiction treatment (Law on Amendments to the Law on Protection from Domestic Violence). ${ }^{5}$ In this regard, in 2013, the security measures oriented toward the perpetrators of violent crimes, primarily regarding the offense of domestic violence, were included in the criminal legislation for the first time, They were also retained in the new criminal legislation of the Republika Srpska. Thus, the current Criminal Code of Republika Srpska ${ }^{6}$ also contains three measures oriented toward the perpetrators of violent crimes within the framework of security measures: the measure prohibiting the perpetrator from approaching and communicating with the victim (Article 79), mandatory psychosocial treatment (Article 80) and the removal of the perpetrator from the joint household (Article 81). The purpose of these measures is to ensure special prevention, which are formulated to prevent the perpetrator from perpetrating offenses in the future. Regarding the perpetrators of violent crimes, security measures are aimed at eliminating the situations and conditions contributing to the commission of future offenses.

The connection between the personality of the perpetrator, the neighborhood, the environment and life opportunities, coupled with some personality traits, contribute to producing a criminal act (Drakić, 2005: 126). The connection between the criminologenic characteristics of personality and

${ }^{3}$ Official Gazette of RS, No. 67/13.

${ }^{4}$ Prior to the amendments and supplements to Chapter V, the former Criminal Code encompassed five measures: mandatory psychiatric treatment (Article 58), mandatory addiction treatment (Article 59), the prohibition on performing professional practice, activity, or duty (Article 60), a driving ban (Article 61), and the forfeiture of items (Article 62).

${ }^{5}$ Official Gazette of RS, No. 108/13.

${ }^{6}$ Official Gazette of RS, No. 64/17 
crime has been investigated within several personality models, ${ }^{7}$ and some of them will be mentioned.

It is likely that the largest number of studies dealing with the relationship between personality traits and crime production originated from a lexical ${ }^{8}$ personality model including five broad traits: extraversion, neuroticism, agreeableness, conscientiousness and openness to experience (Costa \& McCrae, 1992; John, Naumann \& Sotto, 2008). The most reluctant findings describing criminal behavior by means of these traits suggest that the personality profile of offenders is described by, first of all, low cooperation, that is, conscientiousness (Le Couff \& Toupin, 2009; Miller \& Lynam, 2001). The personality trait that distinguishes both male and female perpetrators of violence among partners is a low level of cooperation, that is, a difficult nature, distrust and intransigence, which is very important for understanding personality, that is, behavior (Feist \& Feist, 2009). Research findings (Thorton, Graham-Kevan \& Archer, 2010) demonstrate that this trait, in addition to neuroticism, is more pronounced among the male perpetrators of violence compared to the perpetrators of nonviolent crimes. Additionally, both of these traits are associated with aggression, which produces violent behavior. Emotional instability and low scores regarding the dimension of cooperation "produce" suspicion, the critical and hostile behavior of violent perpetrators (Feist \& Feist, 2009). Expressed neuroticism reflects negative emotions such as anger or anxiety (Stead \& Fekken, 2014).

The connection between the traits of the five-factor model and the phenomenon of criminality was also empirically demonstrated in Serbia, both in the sample of adult convicts (Međedović, Kujačić \& Knežević, 2012a) and institutionalized adolescents (Međedović, Kujačić, Đoković, Jerinić \& Knežević, 2011; Međedović, Kujačić \& Knežević, 2012). Kaspi and his colleagues argued that criminality, among other things, was determined by low self-control and negative affect. These two qualities are inversely proportional, meaning that people with low self-control tend to have high scores regarding negative affect and in the absence of strong social control they cannot keep their anger and irritation under control. Although some individuals may have a genetic basis for a high level of negative affect and low self-control, both features are influenced by the midpoint factors, especially family dynamics involving emotional and physical abuse (Caspi et al., 1994). It is important to bear in mind that all of these characteristics are the result of different types of temperaments and different developmental experiences, and that they (personality traits) are distributed along the continuum, that is, they are not dichotomous. The point is that all people have these qualities, to varying degrees.

Unlike the conditions that may contribute to the commission of 28 offenses, the current psychic "condition" of the perpetrator, which can

\footnotetext{
7 Eysenck's personality model (Eysenck \& Eysenck, 1976), Zuckerman's personality model (Zuckerman, 1994), Five-factor personality model (Costa \& McCrae, 1992), the HEXACO personality model (Lee \& Ashton, 2009). 8 This personality model is based on the lexical hypothesis that all the important individual
differences in personality traits are coded in the words of individual languages.
} 
manifest itself in various forms (mental illness, temporary mental disorder, or mental retardation) may play a more significant role in imposing the security measures on the perpetrators of violent crimes. It is about the psychic factors that contribute to the commission of crimes, such as mental disorders which encompass behavioral disorders and psychological structure which change the characteristics of an individual (psychosis, neurosis, mental deficiency, alcoholism) (Ignjatović, 2011: 186 - 187).

The security measure of mandatory psychosocial treatment is aimed at removing the situation that may contribute to the commission of offenses in the future, while the other two measures (the measure prohibiting the perpetrator from approaching the victim and the removal of the perpetrator from the joint household) are aimed at eliminating the conditions leading to the commission of an offense. Further, since they are non-medical measures, it is possible to combine them with other security measures. In fact, the offense committed may point to several specific aspects of the dangers posed by the perpetrator (Bačić, 2009: 479). In this way, the court may, in addition to the security measure of the removal from the joint household, also impose mandatory addiction treatment or mandatory psychiatric treatment.

\section{SECURITY MEASURES ORIENTED TOWARD THE PERPETRATORS OF VIOLENT CRIMES}

It has already been noted that the new criminal legislation contains three security measures oriented toward perpetrators of violent crimes. In addition to these measures, the legislature prescribed six more security measures that can be imposed on the perpetrators of offences along with the perpetrators of violent crimes. Some of these security measures can also be issued cumulatively: mandatory psychiatric treatment and supervision in a health institution (Article 74), mandatory psychiatric treatment outside an institution (Article 75), mandatory addiction treatment (Article 76), the prohibition on performing professional practice, activity, or duty (Article 77), the prohibition on attending certain sporting events (Article 78), and the forfeiture of items (Article 82). ${ }^{9}$ Nevertheless, the focus is placed on new security measures (at least with regard to the criminal legislation of Republika Srpska).

\section{Prohibition on approaching and communicating with a certain person}

The prohibition on approaching and communicating with a certain person is a security measure imposed by the court on the perpetrator of violent crimes, which is aimed at prohibiting the perpetrator from approaching the victim within a specified distance for a certain period of time and from coming within a specified distance of the premises or workplace, that is, to prohibit

\footnotetext{
${ }^{9}$ For more details, see: Criminal Code of Republika Srpska (Official Gazette of RS, No. 64/17).
} 
further communication with the victim if it may reasonably be expected that the further commission of such acts by the perpetrator would pose a threat of danger to the victim (Article 79, paragraph 1). Additionally, this prohibition may also refer to approaching or communicating with other persons, if such a behavior of the perpetrator would mean a psychological harassment of the victim (Article 79, paragraph 2). The conditions for issuing this measure are two-fold: first, the commission of a violent crime, and second, the justified expectation that the continuation of such acts by the perpetrator would pose a threat of danger to the victim.

As indicated above, a violent crime goes beyond the commission of domestic violence; it may also include the offense of bodily injury or serious bodily injury. The measure consists of a number of prohibitions: the security measure prohibiting the perpetrator from approaching the victim within a specified distance, from coming within a specified distance of the premises or workplace, or from future communication with the victim. Prohibition on coming within a specified distance of the premises or workplace is clearly formulated. In contrast, the distance between the perpetrator of the crime and the victim is determined on a case-by-case basis, whereby the court primarily takes into account the subjective feeling of fear present in the victim. On the other hand, the prohibition on future communication with the victim, in addition to the prohibition on direct communication, implies a ban on contacts by telephone and electronic mail. In essence, the quality of communication, that is, the quantity of emotions and degree of emotional closeness between the perpetrator and the victim prior to the delict are assessed (Kovačević, 2006).

Additionally, the legislature stipulates that the perpetrator of these offenses may also be prohibited from communicating with other persons, if such a behavior would mean the harassment of the victim. These are constellations that indirectly disturb the victim, for example, by communicating threats through that other person, or threatening, for example, family members, if at the same time it represents a psychological harassment of the victim.

Regarding the second condition, the court will issue the appropriate prohibition only when there is reasonable expectation that the undertaking of certain actions is likely to pose a threat of danger to the victim. These actions are usually undertaken following the commission of the criminal offense and this security measure is issued to prevent the perpetrator from "taking such actions" in the future. Therefore, the actions of the post delictum nature are of paramount importance, in other words, the justified expectation that they will pose a threat of danger to the victim or mean a psychological harassment for the victim. It is important to point out that the World Health Organization multicountry study on women's health and domestic violence conducted in several US states (Ellsberg, Jansen, Heise, Watts \& Garcia-Moreno, 2008), confirmed that women who experience intimate partner violence are more likely to have suicidal ideation, attempt suicide more often, and show more emotional distress than women who have not experienced any abuse. The results of meta-analysis, 
which included studies conducted on general population samples, demonstrated that women are more likely to be physically injured by their spouses/partners and are more likely to seek medical care for the injuries than men (Archer, 2000).

The legislature has generally stipulated that the prohibition on approaching and communicating with a certain person can last no more than two years. It lasts as long as the reasons for which it was issued exist (Article 79, paragraph 3), meaning the court exercises control over its implementation and justification. The law also stipulates that the period of time spent in prison, that is, in treatment and custodial facilities, will not be deduced from this measure. In this regard, this measure can be issued alongside of other security measures, through which the conditions leading to the commission of an offence are removed. This measure can also be imposed alongside of the suspended sentence. If the order prohibiting the perpetrator from approach or communication with the victim or another person is breached, the suspended sentence will be revoked and the court will impose the specified punishment.

\section{Mandatory psychosocial treatment}

Another security measure that can be imposed on the perpetrators of violent crimes is mandatory psychosocial treatment (Article 80). Mandatory psychosocial treatment is issued in cases in which, on the basis of the earlier life of the perpetrator and the psychic characteristics of his person, the court determines that there is a risk that the perpetrator will repeat such or similar acts and that a psychosocial treatment is required in order to eliminate this danger (Article 80, paragraph 1). The purpose of the treatment is to stop and prevent further violent behavior by achieving positive changes in the conduct of the perpetrator.

It is necessary to cumulatively achieve two conditions in order to impose a measure: (a) the commission of a violent crime, and (b) a psychosocial treatment is required in order to eliminate this danger. Considering the first condition, it corresponds to the condition which is provided for the measure of Prohibition on approaching and communicating with a certain person. In contrast, the second condition, that is, the existence of a danger that such an offense or a similar one may be repeated, is assessed by the court based on, for example, witness testimonies, criminal records or psychiatric forensic expertise. These offenders of crimes are more socially dangerous than the perpetrators on whom the prohibition on approaching and communicating with a certain person is imposed. These persons have more pronounced character traits that may lead to disharmony between certain psychic functions, that is, insufficient mental and social functioning. The personality disorder most commonly associated with criminal acts and violent behavior is a dissocial personality disorder, described in classical psychiatric literature as a psychopathy. Psychopathy includes predatory behavior, emotional coldness, recklessness, impulsivity, and persistent antisocial behavior (Hare, 2003; Patrick, 2006). According to research 
findings, after having served the prison sentence or after the hospitalization, psychopaths, compared to non-psychopaths, commit more serious violent crimes and are more likely to reoffend (Hemphill, Hare \& Wong, 1998; Leistico, Salekin, DeCoster \& Rogers, 2008). Additionally, behavioral disorders (narcissistic and antisocial personality disorders) are linked to the need for control of others and are particularly characteristic of the male perpetrators of domestic violence (Hamberger \& Hastings, 1988). ${ }^{10}$

Few existing studies on the female perpetrators of intimate partner violence indicate the existence of a borderline, antisocial and dependent personality disorder (Goldenson, Geffner, Foster \& Clipson, 2007; Ross, Gask \& Berrington, 2011; Stuart, Moore, Gordon, Ramsey \& Kahler, 2006). According to the preliminary data, women deprived of their liberty due to domestic violence show more pronounced personality disorders than male perpetrators (Henning, Jones \& Holdford, 2003). Unlike the former security measure which is imposed to prohibit the perpetrator from approaching and communication with the aim of preventing certain actions undertaken after the commission of a specific offense and which can endanger the victim, this measure is imposed after taking into account the facts existing before the commission of a certain offense, which may affect the repetition of such an offense or a similar one. In this regard, the court has no expectations and the court's decision is based on the facts related to the life of the perpetrator and his psychic characteristics. The aim is that the perpetrator gains insight into his actions, to accept responsibility and adopt self-regulation of behavior. The perpetrator learns social skills and changes those beliefs that have contributed to the establishment of violent behaviors within group meetings in which he is actively involved. ${ }^{11}$

The security measure of mandatory psychosocial treatment lasts from six months to two years and is executed alongside of the prison sentence or suspended sentence (Article 80, paragraph 3) in a penitentiary or other appropriate facility, and can be continued outside the appropriate facility after the convicted person has been released on parole. The avoidance of psychosocial treatment represents the basis for revoking release on parole and the suspended sentence, and in this case, instead of the community service sentence, a decision on the execution of the prison sentence will be reached (Article 80, paragraph 4).

${ }^{10}$ In addition to perpetrators, victims may also be subjected to psychosocial treatment. Hamberger \& Guse (2002) reported that women who were ordered by the court to attend counseling regarding domestic violence, including women in shelters, were more likely to feel intense fear and more often sought police help, unlike the male victims of domestic violence who did not take their partner's violence seriously (they were laughing).

11 For more details, see: http://www.psyhoaktiva.hr/tretmanski-centar/psihosocijalni-tretmannasilnika.html. Retieved August 22, 2018. 
Removal from the joint household (Article 8) is the only security measure which states that it should be imposed in respect with the offence of domestic violence. ${ }^{12}$. Thus, the legislature further points to the importance of preventing domestic violence and its consequences..$^{13}$ This measure is imposed on the perpetrator who has committed the crime of violence against the person with whom he or she lives in the joint household, if there is a high degree of danger that the perpetrator will commit the violent act again against a member living in a joint household and, in order to eliminate this danger, it is necessary to remove the perpetrator from the joint household (Article 81, paragraph 1). As in previous cases, certain conditions must be met to apply this security measure. It is about three cumulatively foreseen conditions. On the one hand, the commission of the offense of violence against a person living in the same household is required, while on the other hand, the existence of a high level of danger that the perpetrator will again commit violence against a member of the joint household is required, and finally, the request to remove the perpetrator from the joint household in order to eliminate this danger is emphasized.

Regarding the first condition, by formulating the offense against the person with whom he/she lives "in the joint household", the legislature has limited the possibility of applying this measure. A passive subject (victim) is a person living in the joint household. It is usually a family member but it can also be other people livening in the joint household, from which it can be seen that the circle of passive subjects is expanded. Statistical data on the gender/sex representation of crimes in the sphere of marriage and family in the Republika Srpska in the period from 2011 to 2015, show that female perpetrators were represented in 194 cases (or $8.06 \%$ ) of 2404 offenses $^{14}$. Accordingly, the results

\footnotetext{
${ }^{12}$ Statistical data demonstrate that it is about a constellation positioned immediately after the most frequent crimes, that is, crimes against property, life and body, official duties, public order offenses, environmental crime. Considering the fact that the old Criminal Code contained 19 group protection facilities, crimes against marriage and family were often ranked 5th or 6 th by the number of their commissions. In the period 2010-2015, crimes against marriage and family represented an average of $3.55 \%$ of the total offenses committed. Over a period of six years, an increase in these offenses in the total number of the offenses committed was reported: in 2010, crimes against marriage and family accounted for 520 (or 3.09\%) of 16779 offenses committed; in 2011, 364 (or 2.48\%) of 13169 offenses committed; in 2012, 364 (or 2.92\%) of 12448 offenses committed; in 2013, 436 (or $3.66 \%$ ) of the total of 11901 offenses committed; in 2014, 695 (or 5.03\%) of the total of 13808 offences committed; and in 2015, of the total of 13966 offenses committed, crimes against marriage and family accounted for 582 (or $4.16 \%$ ). For more details, see: Statistical Yearbook of Republika Srpska. Retrieved August 21, 2018, from http://www.rzs.rs.ba/front/category/8/.

${ }^{13}$ The findings of the largest annual victimization survey conducted throughout the world (National Crime Victimization Survey, NCVS) have consistently pointed out that approximately $85 \%$ of all the victims of domestic violence, regardless of whether the incident was reported to the police or not, constituted women (Greenfeld et al, 1998; Healey, Smith \& O'Sullivan, 1998; Rennison \& Welchans, 2000).

${ }^{14}$ For more details, see: Statistical Yearbook of Republika Srpska. Retrieved August 21, 2018, from http://www.rzs.rs.ba/front/category/8/.
} 
of Archer's meta-analysis (2000) confirm that women reprted more frequent use of physical force in partner relationships, in other words, men more frequently inflicted injuries on women than women on men.

The second condition is that the court determines the existence of a "high level of danger" that the perpetrator will again commit a crime of violence. A high level of danger is determined by the court in specific cases, and the circumstances preceding the commission of an offense are taken into account, on the basis of which the court reaches a conclusion that the offense will be committed again. Risk factors of repeat domestic violence include, by frequency, constant and violent jealousy, the control of the partner's daily activities, the struggle for child custody and access to disputes, death threats, stalking, assaulting or threatening with a firearm, and forced sexual intercourse (Juodis, Starzomski, Porter \& Woodworth, 2014).

Attention deficit disorder increases the risk of intimate partner violence, that is, interpersonal conflicts due to the difficulty in listening to others (partners) and the inability to appropriately observe a complex situation (Fang, Massetti, Ouyang, Grosse \& Mercy, 2010). The Revised Danger Assessment (Revised Danger Assessment, DA; Campbell, Webster \& Glass, 2009) carried out in a sample of 37 cases of domestic violence with a fatal outcome, found that they did not appear "out of the blue", that is, in $82.9 \%$ of the cases, it was about premeditated murders, and in $86.5 \%$ of the cases there was a risk of murder (Juodis, et al., 2014). The same study found that in $83.8 \%$ of the cases, the murders were proceeded by more serious and frequent domestic violence. Research findings demonstrated that the perpetrators of these crimes were possessive, vindictive and had a dominant urge to inflict injuries on their spouse. In line with previous studies, previous cases of domestic violence in which women were victims are listed as the most common mortality factor in this context (Campbell, Glass, Sharps, Laughon \& Bloom, 2007). The comparison of demographic characteristics, criminal history, and domestic violence history for 5,578 men and 1,126 women arrested (Henning \& Feder, 2004) demonstrated that male reoffenders of domestic violence and violence in general constituted a larger portion than female reoffenders. ${ }^{15}$

Finally, the third condition for imposing this measure pertains to the necessity of its application. It is only applied if the danger of reoffending violent crimes cannot be eliminated in any other way. Regarding this security measure, the legislature also stipulates its method of execution by providing that the perpetrator on whom this security measure is imposed is obliged to leave the apartment, house or other area that makes a joint household with the victim in the presence of a police officer immediately following the final judgment. The security measure lasts from six months to five years, and at the time of its duration, the time spent by the perpetrator in the penitentiary

\footnotetext{
${ }^{15}$ On the other hand, domestically violent women inflict more severe injuries, have problems finding employment, and are younger. Also, this research demonstrated that violent women had fewer criminal complaints than men, and their partners were less likely to feel seriously endangered. Likewise, men had more problems with drug and/or alcohol abuse.
} 
institution or treatment facility (Article 81, paragraph 2) does not count. Clearly, this measure may be imposed under certain conditions even alongside of the suspended sentence. It should be noted that a suspended sentence is the most common criminal sanction imposed on the perpetrators of crimes against marriage and family. Thus, in the period 2011-2015, of the total of 961 criminal sanctions imposed on the perpetrators of crimes against marriage and family, 824 suspended sentences (85.74\%) were imposed..$^{16}$ This is where the imposition of security measures should come to the fore. In addition to the above, the legislature, as with the previous measures, determined that the non-enforcement of this measure constitutes the basis for the revocation of conditional release (Article 81, paragraph 3), and the solution that a person who has been removed from the household is obliged to contribute to the financial support of persons who have remained in the household in the manner determined by the court has been adopted (Article 81, paragraph 5).

\section{CONCLUSION}

Offenses with the potential for violence represent one of the most significant constellations of criminal behavior. Particularly important issues here include the study of the personality of perpetrators of these offenses and criminal legal responses to the commission of violent crimes. An abundance of research has been conducted on the perpetrators of violent crimes, indicating that the structure of the personality of the perpetrators of these offenses is unique, which are underlied by deeply rooted maladaptive patterns manifesting in a wide range of attitudes toward themselves and the environment.

It is precisely this "deformed" variant of a normal personality without psychopathological contents typical of mentally ill population, along with the biological and psychological components found and the criterion of significantly diminished responsibility that can be taken as a condition for imposing security measures oriented toward perpetrators of violent crimes. This view should be taken as a recommendation, since the legislature of the Republika Srpska prescribes only mental illness, temporary mental disorder and mental retardation as a biological basis for significantly diminished responsibility.

The new Law on Amendments to the Criminal Code of the Republika Srpska provides for security measures that apply to the perpetrators of violent crimes. The perpetrators of these crimes can be prohibited from approaching and communicating with a certain person, they may be ordered to have a mandatory psychosocial treatment and be removed from a joint household. The conditions for imposing these security measures are not identical, which is understandable. They are adapted to the personality of the perpetrator to the highest extent possible. It is important that the application of these security measures removes

${ }^{16}$ For more details, see: Statistical Yearbook of Republika Srpska. Retrieved August 21, 2018, from http://www.rzs.rs.ba/front/category/8/. 
the situations and conditions leading to the commission of violent crimes and that the perpetrator who is no longer dangerous be integrated into society.

\section{REFERENCES}

Archer, J (2000) Sex differences in aggression between heterosexual partners. Psychological Bulletin, 126 (5), 651-680.

Bačić, F. (2009). Opći dio kaznenog prava. Zagreb: Pravni fakultet.

Bartol, C. R. \& Bartol, A. M. (2005). Criminal Behavior - A Psyhchosocial Approach. New Jersey: Pearson.

Campbell, J. C., Glass, N., Sharps, P. W., Laughon, K., \& Bloom, T. (2007). Intimate partner homicide: review and implications of research and policy. Trauma, Violence \& Abuse, 8, 246-269.

Campbell, J. C., Webster, D.W., \& Glass, N. (2009). The danger assessment: validation of a lethality risk assessment instrument for intimate partner femicide. Journal of Interpersonal Violence, 24, 653-674.

Caspi, A., Moffitt, T. E., Silva, P. A., Loeber, M. S., Krueger, R. F., \& Schmutte, P. S. (1994). Are some people crime prone? Replications of the personality crime relationship across countries, genders, races, and methods. Criminology, 32, 163-196.

Costa, P. T., \& McCrae, R. R. (1992). Revised NEO Personality Inventory (NEOPI-R) and NEO Five-Factor Inventory (NEO-FFI) Professional Manual. Odessa, FL: Psychological Assessment Resources.

Дракић, Д. (2005). Сврха мјера безбједности као кривичних санкција. Зборник радова Правног факултета у Новом Саду, 3/2005, 121 - 128.

Ellsberg M, Jansen HA, Heise L, Watts CH, Garcia-Moreno C. (2008). Intimate partner violence and women's physical and mental health in the WHO multi-country study on women's health and domestic violence: an observational study. Lancet 371 (9619), 1165-1172.

Fang X, Massetti G.M., Ouyang L., Grosse S.D., Mercy J.A. (2010). Attention-deficit/ hyperactivity disorder, conduct disorder, and young adult intimate partner violence. Archives of General Psychiatry, 67(11), 1179-1186.

Feist, J. \& Feist, G. J. (2009). Theories of Personality, seventh edition. (408-427). New York, NY: McGraw-Hill Companies.

Goldenson, J., Geffner, R., Foster, S., \& Clipson, C. (2007). Female domestic violence offenders: Their attachment security, trauma symptoms, and personality organization. Violence and Victims, 22, 530-543.

Greenfeld, L., Rand, M., Craven, D., Klaus, P., Perkins, C., Ringel, C., Warchol, G., Matson, C., and Fox, J. A. (1998). Violence by Intimates: Analysis of Data on Crimes by Current or Former Spouses, Boyfriends and Girlfriends (NCJ 167237), US Department of Justice, Bureau of Justice Statistics, Washington, DC. 
Hamberger, L.K., \& Hastings, J.E. (1988). Skills training for treatment of spouse abusers: An outcome study. Journal of Family Violence, 3, 121-130.

Hamberger, L. K. \& Guse, C. E. (2002) Men's and women's use of intimate partner violence in clinical samples. Violence Against Women, 8 (11). 1301-1331.

Hare, R.D. (2003). Hare psychopathy checklist-revised (PCL-R) (2nd ed). Toronto, Canada: Multi-Health Systems.

Healey, K., Smith, C., and O'Sullivan, C. (1998). Batterer Intervention: Program Approaches and Criminal Justice Strategies, US Department of Justice, Washington, DC.

Hemphill, J., Hare, R. \& Wong, S. (1998). Psychopathy and recidivism: A review. Legal Criminological Psychology, 3, 141-172.

Henning, K., Jones, A. \& Holdford, R.J. (2003). Treatment needs of women arrested for domestic violence: A comparison with male offenders. Journal of Interpersonal Violence, 18, 839-856.

Henning, K. \& Feder, L. (2004). A Comparison of Men and Women Arrested for Domestic Violence: Who Presents the Greater Threat? Journal of Family Violence, 19(2), 69-80.

Holtzworth-Munroe, A., and Stuart, G. (1994). Typologies of male batterers: Three subtypes and the differences among them. Psychol. Bull. 116(3), 476-497.

Игњатовић, Ђ. (2011). Појам и етиологија насилничког криминалитета. Crimen, 2, $181-212$.

John, O. P., Naumann, L. P., \& Soto, C. J. (2008). Paradigm shift to the integrative BigFive trait taxonomy: History, measurement, and conceptual issues. In O. P. John, R. W. Robins, \& L. A. Pervin (Eds.), Handbook of Personality: Theory and Research, 3rd ed. (pp. 114-158). New York, NY: Guilford Press.

Johnson, M. (1995). Patriarchal terrorism and common couple violence: Two forms of violence against women. J. Marriage Fam, 57, 283- 294.

Juodis, M., Starzomski, A., Porter, S. \& Woodworth, M. (2014). What Can be Done About High-Risk Perpetrators of Domestic Violence? Journal of Family Violence, 29, 381-390.

Ковачевић, Р. (2006). Убиство у породици. Београд: Институт за криминолошка и социолошка истраживања.Le Couff, Y., \& Toupin J. (2009). Comparing persistent juvenile delinquents and normative peers with the Five-Factor Model of personality. Journal of Research in Personality, 43, 1105-1108.

Кривични законик Републике Српске („Службени гласник PС“, број 64/17).

Le Couff, Y., \& Toupin J. (2009). Comparing persistent juvenile delinquents and normative peers with the Five-Factor Model of personality. Journal of Research in Personality, 43, 1105-1108.

Leistico, A.R., Salekin, R.T., DeCoster, J., \& Rogers, R. (2008). A large-scale metaanalysis relating the Hare measures of psychopathy to antisocial conduct. Law and Human Behavior, 32, 28-45. 
Levi, M. \& Maguire, M. (2002). Violent crime. In: The Oxford Handbook of Criminology (рp. 795-843). Oxford: Oxford University Press.

Марковић, И. (2007). Основи криминлогогије. Бања Лука: Правни факултет.

Међедовић, Ј., Кујачић, Д., Ђоковић, Н., Јеринић, М. \& Кнежевић, Г. (2011). Предикција Аморалности код осуђеника са изреченом мером обавезног лечења наркомана у Специјалној затворској болници у Београду. У: Књига резимеа са XVII научног скупа Емпиријска истраживања у психологији.(стр. 196-197). Београд: Филозофски факултет, Универзитет у Београду.

Međedović, J., Kujačić, D., \& Knežević, G. (2012). Personality-related determinants of criminal recidivism. Psihologija, 45, 277-294.

Међедовић, Ј., Кујачић, Д., и Кнежевић, Г. (2012а). Личносне диспозиције ка криминалном рецидиву у узорку институционализованих адолесцената. Зборник Института за криминолошка и социолошка истраживања, 31, 7-24.

Miller, J. D., \& Lynam, D. (2001). Structural models of personality and their relation to antisocial behavior: a meta-analytic review. Criminology, 39, 765-798.

Patrick, C.J. (Ed.). (2006). Handbook of psychopathy. New York: Guilford Press.

Rennison, C. M., and Welchans, S. (2000). Intimate Partner Violence. US Department of Justice, Office of Justice Programs,Washington, DC.

Ross, H., Gask, K., \& Berrington, A. (2011). Civil partnership five years on. Population Trends, 145(1), 172-202.

Статистички годишњак Републике Српске, доступно на http://www.rzs.rs.ba/ front/category/8/, приступљено 21. 08. 2018. године.

Stead, R. \& Fekken, G.C. (2014). Agreeableness at the Core of the Dark Triad of Personality. Individual Differential Research, 12 (4-A), (131-141).

Stuart, G.L., Moore, T.M., Gordon, K.C., Ramsey, S.E., \& Kahler, C.W. (2006). Psychopathology in women arrested for domestic violence. Journal of Interpersonal Violence, 21, 376-389.

Thornton, A. J. V., Graham-Kevan, N., \& Archer, J. (2010). Adaptive and maladaptive personality traits as predictors of violent and nonviolent offending behavior in men and women. Aggressive Behavior, 36, 177-186.

Wallace, H., Seymour, A.: „Domestic violence“; (eds) Coleman, G.; Gaboury, M.; Murray, M.; Seymour, A.; National Victim Assistence Academy; Washington, DC, U.S., Department of Justice, 2007, преузето са https://www.ovc.gov/, приступљено 21. 06. 2018. године.

Закон о измјенама и допунама Закона о заштити од насиља у породици („Службени гласник РС“, број 108/13).

Закон о измјенама и допунама Кривичног закона Републике Српске („Службени гласник РС“, број 67/13).

Paper received on: 04. 02. 2019.

Paper accepted for publishing on: 29. 03. 2019. 


\section{МЈЕРЕ БЕЗБЈЕДНОСТИ ОРИЈЕНТИСАНЕ КА ИЗВРШИОЦИМА КРИВИЧНИХ ДЈЕЛА СА ЕЛЕМЕНТИМА НАСИЉА У РЕПУБЛИЦИ СРПСКОЈ}

Прегледни научни рад

\begin{tabular}{|l|l|l|} 
DOI 10.7251/ZBK1901027V & COBISS.RS-ID 8272664 & УДК 343.13:343.211.3]:351.74(497.6PC) \\
\hline
\end{tabular}

Жана Врућинић ${ }^{1}$

Факултет безбједносних наука, Универзитет у Бањој Луци

Драгана Васиљевић

Факултет безбједносних наука, Универзитет у Бањој Луци

Апстракт: Насиље, као деструктивни облик понашања, одувијек је било заступљено у интерактивним односима. Одређени облици његовог испољавања законодавства предвиђају као кривична дјела и за њих прописују одговарајуће кривичне санкције. Ово је случај и са Кривичним закоником Републике Српске који је задржао рјешење из Закона о измјенама и допунама Кривичног закона Републике Српске из 2013. године када су уведене одређене новине у погледу кривичноправне реакције на кривична дјела са елементима насиља. Аутори у раду пажњу посвећују особинама личности које извршавају кривична дјела са елементима насиља, као и мјерама безбједности оријентисаним ка извршиоцима кривичних дјела са елементима насиља у кривичном законодавству Републике Српске.

Кључне ријечи: насиље, кривично дјело, извршилац кривичног дјела, мјере безбједности.

\section{ОПШТЕ НАПОМЕНЕ О НАСИЛНИЧКОМ КРИМИНАЛИТЕТУ И МЈЕРАМА БЕЗБЈЕДНОСТИ}

Насиље, без обзира на то да ли је оно организовано или насумично, непрекидно или повремено, интензивно или неконтролисано, увијек повређује или уништава објекат ка коме је усмјерено, или то покушава (Bartol \& Bartol, 2005: 241). У питању је феномен којег није лако објаснити. Тешкоће дефинисања кривичних дјела са елементима насиља произилазе, прије свега, из чињенице да се могу екстензивно схватити, па се као исправна могу

\footnotetext{
${ }^{1}$ Аутор за коресподенцију: др Жана Врућинић, доцент на Факултету безбједносних наука, универзитет у Бањој Луци. E-mail: zana.vrucinic@fbn.unibl.org
} 
узети схватања да свако кривично дјело представља својеврстан облик насиља. С правом истичу Леви и Магуире (Levi \& Maguire, 2000) да је у питању „клизав“ термин који покрива веома широк опсег активности почевши од терористичких напада, банди, уличних разбојништава, па до породичног насиља између брачних партнера које се, опет, може кретати од убиства и силовања па до увреда које узрокују психичке повреде (Levi \& Magiure, 2002: 796). Ријеч је о облицима кривичних дјела код којих се за остварење циља користи напад на жртву или се жртви пријети (Марковић, 2007: 203-204). Човјек се овдје издваја као јединствено биће, малигна агресија која се јавља код њега није филогенетски програмирана. Једино он може да мучи и убија припаднике своје врсте, а да при томе осјећа задовољство (Ковачевић, 2006 :14).

Кривичноправна реакција на предузимање радњи са елементима насиља усмјерена је у два правца. Одређена људска понашања се квалификују као кривична дјела. На овај начин законодавац пружа кривичноправну заштиту појединим правним добрима. ${ }^{2}$ Кривична дјела са предзнаком насиља према којима су управљене мјере безбједности, а које су предмет ове расправе, налазе се (најчешће) у глави Кривична gјела йройив брака и йороguие. Ова врста насиља које се такође означава као „насиље међу партнерима“ или „насиље међу супружницима“ представља сваку увреду, застрашивање, сексуалне увреде, као и сваки други преступ који може да проузрокује тјелесну повреду или смрт некога од чланова породице или некога ко је настањен у истом домаћинству (Wallace \& Seymour, 2007: 299). Неки истраживачи (Johnson, 1995) претпостављају различите облике партнерског насиља и/ или различите типове агресора. У истраживањима која користе клиничке узорке (испитаници из сигурних кућа и испитаници који су потражили љекарску помоћ или пријавили насиље), партнерско насиље се описује као

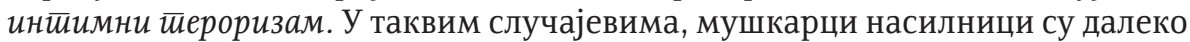
надмоћнији од жена извршилаца, агресија је у великој мјери једнострана (осим у случају самоодбране), чешћа је и нагло ескалира. С друге стране, у истраживањима партнерског насиља на узорку опште популације насиље се у великој мјери описује као зајеgничко. Овај облик агресије је мање озбиљан, ређе се појављује, не ескалира током времена и обично укључује оба партнера која користе физичку силу у току сукоба.

Извршиоци зајеgничкоі̄ (породичног) насиља се са својим супружницима/партнерима укључују у блаже форме физичке агресије, и не врше кривична дјела изван породице. У суштини, ови појединци се не разликују од ненасилних појединаца који имају поремећене брачне односе.

$26{ }^{2}$ Кривична дјела са елементима насиља по природи ствари нису систематизована на начин да се налазе само у једној глави у оквиру Кривичног законика. Напротив, прожимају се кроз читав посебни дио Кривичног законика (нпр. кривична дјела против живота и тијела, кривична дјела против полног интегритета, кривична дјела против јавног реда и мира, кривична дјела против брака и породице, кривична дјела против слобода и права грађана, кривична дјела против имовине и слично). С тим у вези, може се истаћи да она чине највећи број од укупно извршених кривичних дјела, вид. Статистички годишњак Републике Српске, доступно на http://www.rzs. rs.ba/front/category/8/, приступљено 21. 08. 2018. године. 


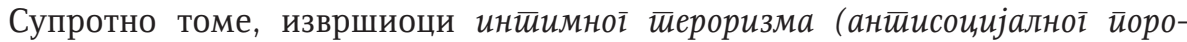
gичноі насиља) (Holtzworth-Munroe \& Stuart, 1994) укључују се у озбиљно физичко, сексуално и психолошко злостављање својих партнера. Њих одликују негативни ставови према женама, злоупотреба алкохола, наркотика, односно, широк спектар друштвено непожељних понашања.

Инкриминисање оваквих понашања представља правни оквир за други вид кривичноправног реаговања, а то су кривичне санкције. Да управо код ових кривичних дјела до изражаја долази личност извршиоца кривичног дјела (насилника) и да поред жртве и о њој правосуђе треба да води рачуна, свједочи увођење нових мјера безбједности у наше кривично законодавство. Овим, по својој природи, допунским кривичним санкцијама појачава се превентивни учинак казне. С тим у вези је и чињеница да су научна сазнања и практична искуства показала да се сузбијање криминалитета одређених криминолошких категорија не може остварити само примјеном казне (Дракић, 2005:123). Законодавац је овдје експлицитан: у оквиру опште сврхе кривичних санкција, сврха мјера безбједности је да се отклоне стања или услови који могу утицати да учинилац убудуће врши кривична дјела (чл. 71).

Систем мјера безбједности до усвајања Закона о измјенама и допунама Кривичног закона Републике Српске ${ }^{3}$ није у својим одредбама садржавао мјере безбједности усмјерене према учиниоцима кривичних дјела са елементима насиља. ${ }^{4}$ Међутим, у оквиру реформе прекршајног законодавства, Закон о измјенама и допунама Закона о заштити од насиља у породици је у члану 23а предвидио одговарајуће заштитне мјере и то: удаљење из стана, куће или неког другог стамбеног простора, забрана приближавања жртви насиља у породици или породичној заједници, забрана узнемиравања или ухођења жртве насиља у породици или породичној заједници, обавезан психосоцијални третман и обавезно лијечење од зависности (Закон о измјенама и допунама Закона о заштити од насиља у породици). ${ }^{5}$ С тим у вези, и у кривично законодавство су 2013. године први пут уврштене мјере безбједности оријентисане ка извршиоцима кривичних дјела са елементима насиља, превасходно у кривичном дјелу Насиље у породици и породичној заједници. Оне су се задржале и у новом кривичном законодавству Републике Српске. Тако, данас Кривични законик Републике Српске ${ }^{6}$ у оквиру мјера безбједности садржи и три мјере оријентисане ка учиниоцима кривичних дјела са елементима насиља: забрана приближавања и комуникације са одређеним лицем (чл. 79), обавезан психосоцијални третман (чл. 80) и удаљење из заједничког домаћинства (чл. 81). То су кривичне санкције које су оријенти-

3 „Службени гласник РС“, број 67/13

${ }^{4}$ Некадашњи Кривични закон је прије измјена и допуна у глави В обухватао пет мјера: обавезно психијатријско лијечење (члан 58), обавезно лијечење од зависности (члан 59), забрана вршења позива, дјелатности или дужности (члан 60), забрана управљања моторним возилом (члан 61) и одузимање предмета (члан 62).

\footnotetext{
5 „Службени гласник РС“, број 108/13

6 „Службени гласник РС“, број 64/17
} 
сане ка учиниоцу кривичног дјела. Сврха им је специјална превенција, формулисана као спречавање будућих кривичних дјела која се могу очекивати од извршиоца. Када су у питању извршиоци кривичних дјела са елементима насиља, мјере безбједности су оријентисане и ка отклањању стања и ка отклањању услова који могу погодовати будућем извршењу кривичних дјела.

Под условима се подразумијева повезаност између личности извршиоца и околине, средине и животних прилика. Ријеч је о условима који у стицају са неким својствима личности дјелују криминогено (Дракић, 2005: 126). Повезаност криминогених особина личности и криминалитета испитивана је у оквиру неколико модела личности, ${ }^{7}$ а за потребе овог чланка ће се навести само неки од њих.

Вјероватно је највећи број истраживања која се баве повезаношћу особина личности и продукције криминалитета настао у оквиру лексичког $^{8}$ модела личности који подразумијева пет широких црта: екстраверзију, неуротицизам, сарадљивост, савјесност и отвореност за искуства (Costa \& McCrae, 1992; John, Naumann \& Sotto, 2008). Најрепликабилнији налази који описују криминално понашање помоћу ових црта сугеришу да профил личности прекршилаца описују, прије свега, ниска сарадљивост и савјесност (Le Couff \& Toupin, 2009; Miller \& Lynam, 2001). Црта личности која одликује како мушке тако и женске извршиоце насиља међу партнерима је ниска сарадљивост, односно, тешка нарав, неповјерење и непопустљивост и врло је значајна за разумијевање личности, односно, понашања (Feist \& Feist, 2009). На основу налаза истраживања (Thorton, Graham-Kevan \& Archer, 2010), ова особина је, поред неуротицизма, код мушких извршиоца насиља међу партнерима у односу на извршиоце ненасилних кривичних дјела, више изражена. Поред тога, обје особине су повезане са агресијом, која и производи насилничко понашање. Емоционална нестабилност и ниски скорови на димензији сарадљивост „производе” сумњичавост, критичко и непријатељско понашање насилних извршилаца (Feist \& Feist, 2009). Изражен неуротицизам одражава негативне емоције као што су љутња или анксиозност (Stead \& Fekken, 2014).

Повезаност између црта петофакторског модела и феномена криминалитета емпиријски је показана и у Србији, како на узорку одраслих осуђеника (Међедовић, Кујачић \& Кнежевић, 2012а), тако и код институционализованих адолесцената (Међедовић, Кујачић, Ђоковић, Јеринић \& Кнежевић, 2011; Међедовић, Кујачић \& Кнежевић, 2012). Каспи и његове колеге су тврдили да је криминалитет, између осталог, одређен ниском самоконтролом и негативним афектом. Те двије особине су обрнуто сразмјерне, што значи да особе са ниском самоконтролом имају тенден-

\footnotetext{
${ }_{7}^{7}$ Ајзенков модел личности (Eysenck \& Eysenck, 1976), Закерманов модел личности (Zuckerman, 1994), Петофакторски модел личности (Costa \& McCrae, 1992), модел личности HEXACO (Lee \& Ashton, 2009).

${ }^{8}$ Овај модел личности заснива се на лексичкој хипотези да су све важне индивидуалне разлике у особинама личности кодиране у ријечима појединих језика.
} 
цију да имају високе скорове који се тичу негативног афекта и у одсуству снажне социјалне контроле не могу своју љутњу и раздражљивост држати под контролом. Иако неки појединци могу имати генетску основу за висок ниво негативног афекта и ниску самоконтролу, обје особине су под утицајем срединских фактора, посебно породичне динамике која укључује емоционално и физичко злостављање (Caspi et al, 1994). Важно је имати на уму да су све те особине резултат различитих врста темперамената и различитих развојних искустава, као и то да су оне (особине личности) распоређене по континууму тј. да нису дихотомне. Суштина је у томе да сви људи посједују те особине, само у различитом степену.

За разлику од услова који могу погодовати будућем извршењу кривичних дјела, за примјену мјера безбједности за учиниоце кривичних дјела са елементима насиља, можда је значајније психичко „стање“ у којем се налази учинилац кривичног дјела, које може да се испољи у различитим појавним облицима (душевна болест, привремена душевна поремећеност и заосталност у душевном развоју). У питању су психички фактори који погодују извршењу кривичног дјела. Најчешће се ради о менталним поремећајима који обухватају поремећаје понашања и психичке структуре мијењајући особине човјека (психозе, неурозе, менталне дефицијенције, алкохолизам) (Игњатовић, 2011: 186-187).

Мјера безбједности обавезног психосоцијалног третмана усмјерена је ка отклањању стања које може погодовати извршењу будућег кривичног дјела, док су остале двије мјере (забрана приближавања и комуникације са одрећеним лицем, односно, удаљење из заједничког домаћинства) оријентисане ка отклањању услова који су погодовали извршењу кривичног дјела. Надаље, како је ријеч о мјерама немедицинског карактера могућа је њихова кумулација са другим мјерама безбједности. Наиме, може се десити да извршено кривично дјело може да указује на више специфичних видова извршиочеве опасности (Вас̌ić, 2009: 479). Тако се може десити да суд поред мјере безбједности удаљења из заједничког домаћинства изрекне и мјеру безбједности обавезног лијечења од зависности, или нпр. обавезног психијатријског лијечења.

\section{МЈЕРЕ БЕЗБЈЕДНОСТИ ОРИЈЕНТИСАНЕ ПРЕМА ИЗВРШИОЦИМА КРИВИЧНИХ ДЈЕЛА СА ЕЛЕМЕНТИМА НАСИЉА}

Већ смо нагласили да ново кривично законодавство садржи три мјере безбједности које су оријентисане ка извршиоцима кривичних дјела са елементима насиља. Поред њих, законодавац је прописао још шест мјера безбједности које се могу изрећи учиниоцима кривичних дјела, па самим тим и извршиоцима кривичних дјела са елементима насиља. Поједине од ових мјера безбједности се могу изрећи и кумулативно: обавезно психијатријско лијечење и чување у здравственој установи (чл. 74), обавезно психијатријско 
лијечење на слободи (чл. 75), обавезно лијечење од зависности (чл. 76), забрана вршења позива, дјелатности или дужности (чл. 77), забрана присуствовања одређеним спортским приредбама (чл. 78) и одузимање предмета (чл. 82). ${ }^{9}$ Ипак, фокус ће се задржати на нове мјере безбједности (барем када је у питању кривично законодавство у Републици Српској).

\section{Забрана ириближавана и комуникаиије са о оређеним лиием}

Забрана приближавања и комуникације са одређеним лицем је мјера безбједности коју суд изриче учиниоцу кривичног дјела са елементима насиља, а суштина мјере је да се за одређено вријеме забрани приближавање оштећеном на одређеној удаљености, забрани приступ у простор око мјеста становања или мјеста рада, односно, да се забрани даља комуникација са оштећеним, ако се оправдано може очекивати да би даље вршење таквих радњи од учиниоца кривичног дјела било опасно по оштећеног (чл. 79 ст. 1). Поред наведеног, забрана из ове мјере безбједности може се односити и на приближавање, односно, комуникацију и са другим лицем, уколико би такво понашање учиниоца представљало психичко узнемиравање оштећеног (чл. 79 ст. 2). Услови за изрицање ове мјере постављени су кумулативно: прво, извршење кривичног дјела са елементима насиља и друго, оправдано очекивање да би наставак вршења таквих радњи учиниоца био опасан по оштећеног.

Јасно је да кривично дјело са елементима насиља не подразумијева, како је и наведено, само извршење Насиља у породици и породичној заједници; то може бити и кривично дјело нпр. Тјелесне йовреgе или Тешке ијјелесне йовреge. Мјера се састоји из низа забрана и то: забране приближавања оштећеном на одређеној удаљености, забране приступа у простор око мјеста становања или мјеста рада и, коначно, забрану будуће комуникације са оштећеним. Забрана приступа у простор око мјеста становања и мјеста рада је јасно формулисана. За разлику од наведеног, раздаљина између учиниоца кривичног дјела и жртве одређује се факултативно, од случаја до случаја, при чему суд превасходно узима у обзир субјективни осјећај страха који је присутан код жртве. С друге стране, забрана будуће комуникације са оштећеним, поред забране непосредне комуникације, подразумијева и забрану како телефонске, тако и комуникацију електронским путем. У суштини, процјењује се квалитет комуникација, тј. квантум емоција и степен емоционалне блискости између починиоца и жртве прије деликта (Ковачевић, 30 2006).

Поред наведеног, законодавац је у посебној одредби нагласио да се извршиоцу ових кривичних дјела може забранити и комуникација са другим лицем, уколико би такво понашање представљало узнемиравање оштећеног. Ријеч је о констелацијама у којима се на посредан начин узнемирава жртва,

\footnotetext{
${ }_{9}^{9}$ Видјети Кривични законик Републике Српске („Службени гласник РС“, број 64/17).
} 
нпр. преношењем пријетњи путем тог другог лица, или пријетње нпр. члановима породице ако то истовремено представља и психичко узнемиравање жртве.

Када је у питању други услов, суд ће одговарајућу забрану изрећи само онда када се оправдано може очекивати да би реализација појединих дјелатности била опасна по оштећеног. Ријеч је о дјелатностима које слиједе након извршеног кривичног дјела, што иницира да се ова мјера безбједности изриче да би се превентивно дјеловало на учиниоца да „даље“ не предузима „такве радње“. Дакле, од претежног значаја су дјелатности йосй gелиu, йум карактера, односно, оправдано очекивање да ће оне бити опасне по оштећеног или ће за њега представљати психичко узнемиравање. Значајно је истаћи да је у студији Свјетске здравствене организације (WHO) у вези са менталним здрављем и породичним насиљем, која је спроведена у више америчких држава (Ellsberg, Jansen, Heise, Watts \& Garcia-Moreno, 2008), потврђено да жене које трпе насиље свог партнера чешће имају суицидалне мисли, чешће покушавају суицид и показују више емоционалног дистреса у односу на жене које нису злостављане. Резултати мета-анализе, која је укључивала првенствено истраживања на узорцима из опште популације, показали су да је већа вјероватноћа да ће жене бити физички повређене од стране супружника/партнера и да ће захтијевати медицинску бригу за те повреде, а не обрнуто (Archer, 2000).

Законодавац је генерално одредио да забрана приближавања и комуникације са одређеним лицем може трајати најдуже двије године. Она траје док трају разлози због којих је изречена (чл. 79 ст. 3), што значи да суд врши контролу над њеним спровођењем и њеном оправданошћу. Такође је предвиђено да се вријеме проведено у затвору, односно, установи за лијечење и чување не урачунава у вријеме трајања ове мјере. С тим у вези, ова мјера се може изрећи кумулативно и са другим мјерама безбједности, путем којих се код учиниоца кривичног дјела отклањају стања која су проузроковала његово извршење. Мјера се може изрећи и уз условну осуду. Уколико лице прекрши забрану приближавања, односно, комуникације са оштећеним или са другим лицем, условна осуда ће се опозвати и суд ће изрећи утврђену казну.

\section{Обавезан иисихосоиијални итреимман}

Друга мјера безбједности која се може изрећи извршиоцима кривичних дјела са елементима насиља је Обавезан психосоцијални третман (члан 80). Обавезан психосоцијални третман се изриче у случајевима када на основу ранијег живота учиниоца и психичких карактеристика његове личности суд утврди да постоји опасност да ће поновити такво или слично дјело и да је ради отклањања ове опасности потребан психосоцијални третман (чл. 80 ст. 1). Сврха третмана је заустављање и спречавање даљег насилничког 
понашања постизањем позитивних промјена у понашању извршиоца кривичног дјела.

И овдје је за изрицање мјере потребно кумулативно остварити два услова: прво: извршено кривично дјело са елементима насиља, и друго: да је ради отклањања ове опасности потребан психосоцијални третман. Што се тиче првог услова, он кореспондира са условом који је предвиђен код мјере Забране ириближавања и комуникаиије са одређеним лиием. За разлику од наведеног, други услов, односно, постојање опасности ради понављања таквог или сличног кривичног дјела, суд цијени на основу нпр. исказа свједока, казнених евиденција или психијатријског вјештачења. Овдје се ради о учиниоцима кривичних дјела који су друштвено опаснији од извршилаца којима се изриче мјера безбједности забране приближавања и комуникације са одређеним лицем. Ове особе одликују израженије карактерне особине које доводе до дисхармоније између појединих психичких функција, односно, до инсуфицијентног менталног и социјалног функционисања. Поремећај личности који се најчешће доводи у везу са криминалним радњама и насилничким понашањем је дисоцијални поремећај личности, у класичној психијатријској литератури описиван као психопатија. Психопатија укључује предаторско понашање, емоционалну хладноћу, безобзирност, импулсивност и перзистентно антисоцијално понашање (Hare, 2003; Patrick, 2006). Према резултатима истраживања психопате након упућивања на извршавање казне затвора или након хоспитализације чине озбиљнија кривична дјела са елементима насиља, и вјероватније је да ће, у односу на непсихопате, бити рецидивисти (Hemphill, Hare \& Wong, 1998; Leistico, Salekin, DeCoster \& Rogers, 2008). Поред тога, поремећаји понашања (нарцистички и антисоцијални поремећај личности) повезани су са потребом за контролом других и посебно одликују мушкарце починиоце насиља у породици (Hamberger \& Hastings, 1988). ${ }^{10}$

Мали број постојећих истраживања у вези са женама извршиоцима партнерског насиља указује на постојање граничног, антисоцијалног и зависног поремећаја личности (Goldenson, Geffner, Foster \& Clipson, 2007; Ross, Gask \& Berrington, 2011; Stuart, Moore, Gordon, Ramsey \& Kahler, 2006). Према прелиминарним подацима, жене лишене слободе због насиља у породици показују израженије поремећаје личности у односу на мушкарце изршиоце (Henning, Jones \& Holdford, 2003). Овдје се за разлику од претходне мјере безбједности, код које се забрана приближавања и комуникације изриче са циљем спречавања одређених радњи, које се реализују након извршења конкретног кривичног дјела, а које могу угрожавати оштећеног, ова мјера изриче узимајући у обзир чињенице које су постојале прије извр-

${ }_{10}$ Поред извршиоца кривичног дјела, психосоцијалном третману могу бити подвргнуте и жртве. Хамбергер и Гусе (Hamberger \& Guse, 2002) су саопштили да су жене којима је одлуком суда било наложено да присуствују савјетовању у вези са насиљем у породици, као и жене у прихватилиштима (склоништима) чешће осјећале интензиван страх и чешће тражиле помоћ полиције, за разлику од мушкараца жртава породичног насиља, који нису озбиљно схватали породично насиље свог партнера (исмијавали су се). 
шења конкретног кривичног дјела, а које могу утицати на то да се понови такво или слично кривично дјело. С тим у вези, суд овдје нема очекивања већ одлуку заснива на чињеницама везаним за ранији живот учиниоца и његове психичке карактеристике. Циљ је да извршилац кривичног дјела стекне увид у своје дјела, да прихвати одговорност и усвоји самоконтролу понашања. У оквиру групних сусрета у којима извршилац кривичног дјела активно учествује, он учи социјалне вјештине и мијења она увјерења која су допринијела успостављању насилничког понашања. ${ }^{11}$

Мјера безбједности обавезног психосоцијалног третмана траје од шест мјесеци до двије године, извршава уз издржавање казне затвора или уз условну осуду (чл. 80 ст. 3), и то у установи за извршење казне затвора или другој одговарајућој установи, а може се наставити изван одговарајуће установе након што је осуђени условно отпуштен). Избјегавање подвргавања психосоцијалном третману представља основ за опозив условног отпуста, као и условне осуде, а у овом случају ће се умјесто изреченог рада за опште добро на слободи донијети одлука о извршењу казне затвора (чл. 80 ст. 4).

\section{Уяаљење из заједничкої домаћинсиива}

Удаљење из заједничког домаћинства (чл. 81) је једина мјера безбједности код које је назначено да се изриче у погледу кривичног дјела Насиље

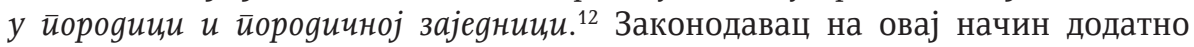
указује на значај спречавања породичног насиља и његових посљедица. ${ }^{13}$ Ова мјера се изриче учиниоцу који је извршио кривично дјело са елемен-

${ }_{11}$ О овоме упор. http://www.psyhoaktiva.hr/tretmanski-centar/psihosocijalni-tretman-nasilnika. html, приступљено 22.08. 2018. године.

12 Статистички подаци показују да се ради о костелацији која се налази одмах након најфреквентнијих кривичних дјела, тј. кривичних дјела против имовине, против живота и тијела, јавног реда и мира, службене дужности, правног саобраћаја и кривичних дјела против животне средине. С обзиром на то да је у тадашњем Кривичном закону било заступљено 19 групних објеката заштите, кривична дјела против брака и породице се по броју њиховог извршења најчешће налазе на петом или шестом мјесту. У периоду од 2010. до 2015. године кривична дјела против брака и породице партиципирала су у просјеку са 3,55\% укупно извршених кривичних дјела. У периоду од шест година примјетан је пораст ових кривичних дјела у укупном броју извршених кривичних дјела: 2010. године од 16779 извршених кривичних дјела 3,09\% или 520 чинила су кривична дјела против брака и породице, 2011. године од 13169 извршених кривичних дјела $2,48 \%$ или 364,2012 . године од 12448 извршених кривичних дјела 364 или 2,92\%, 2013. године од укупно 11901 извршених кривичних дјела 436 или 3,66\%, 2014. године од укупно 13808 извршених кривичних дјела 695 или 5,03\% и у 2015. години од укупно извршених 13966 кривичних дјела извршена су 582 кривична дјела против брака и породице или 4,16\%, вид. Статистички годишњак Републике Српске, доступно на http://www.rzs.rs.ba/ front/category/8/, приступљено 21. 08. 2018. године.

${ }^{13}$ Резултати највеће годишње анкете о виктимизацији која се спроводи широм свијета, (National Crime Victimization Survey, NCVS), досљедно су указивали на то да су приближно 85 \% свих жртава насиља у породици, без обзира да ли је инцидент пријављен полицији или не, биле жене (Greenfeld et al, 1998; Healey, Smith \& O'Sullivan, 1998; Rennison \& Welchans, 2000). 
тима насиља према лицу са којим живи у заједничком домаћинству, ако постоји висок степен опасности да ће учинилац поново извршити насиље према члану заједничког домаћинства и да је ради отклањања ове опасности неопходно његово удаљење из заједничког домаћинства (чл. 81 став 1). Као и у претходним случајевима, за примјену и ове мјере безбједности неопходно је остварити одређене услове. Ријеч је о три кумулативно предвиђена услова. Са једне стране, захтијева се извршење кривичног дјела са елементима насиља према лицу које живи у заједничком домаћинству, док се са друге стране захтијева и постојање високог степена опасности да ће учинилац поново извршити насиље према члану заједничког домаћинства и, на крају, истиче се захтјев да је ради отклањања ове опасности неопходно његово удаљење из заједничког домаћинства.

Када је ријеч о првом услову, законодавац је формулацијом да се кривично дјело врши према лицу са којим се живи „у заједничком домаћинству“, ограничио могућност примјене ове мјере. Пасивни субјект (жртва) је особа која живи у заједничком домаћинству. Обично се ради о члану породице и породичне заједнице, али то могу бити и друга лица која се налазе у заједничком домаћинству из чега се види да је круг пасивних субјеката проширен. Статистички податак о полној заступљености кривичних дјела из области брака и породице у Републици Српској у периоду од 2011. до 2015. године, гдје су од укупно 2404 извршена кривична дјела, жене извршиоци биле заступљене у 194 случаја (8,06\%). ${ }^{14}$ У складу са тим, резултати метаанализе Archer-a (2000) потврђују да жене нешто чешће од мушкараца пријављују употребу физичке силе у партнерским везама, односно, да мушкарци чешће наносе повреде женама.

Други услов је да суд утврди постојање „високог степена опасности“ да ће учинилац поново извршити кривично дјело са елементима насиља. Висок степен опасности суд утврђује у конкретним случајевима, и овдје се у обзир узимају околности које су претходиле извршењу кривичног дјела, a на основу којих се суд стиче увјерење да ће кривично дјело поново бити извршено. Као фактори ризика поновљеног породичног насиља наводе се, по учесталости, константна и насилна љубомора, контролисање свакодневних активности партнера, борба за старатељство над дјецом и приступ споровима, пријетња смрћу, праћење, пријетња или напад оружјем и присилни секс (Juodis, Starzomski, Porter \& Woodworth, 2014).

Поремећај пажње повећава ризик од партнерског насиља, односно, интерперсоналних конфликата због потешкоћа у слушању других (партнера) и немогућности адекватног опажања комплексне ситуације (Fang, Massetti, 34 Ouyang, Grosse \& Mercy, 2010). Ревидираним Упитником за процјену ризика (Revised Danger Assessment, DA; Campbell, Webster \& Glass, 2009) на узорку од 37 случајева насиља у породици са смртним исходом, откривено је да се

\footnotetext{
${ }_{14}$ Вид. Статистички годишњак Републике Српске, доступно на http://www.rzs.rs.ba/front/ category $/ 8 /$

приступљено 21. 08. 2018. године.
} 
они нису појавили „из ведра неба”, односно, да је у 82,9\% случајева било ријечи о планираним убиствима, а у $86,5 \%$ случајева постојао је ризик од убиства (Juodis, et al., 2014). У истом истраживању нађено је да је у 83,8 \% случајева претходило озбиљније и учесталије породично насиље. Резултати су показали да су извршиоци ових кривичних дјела посесивни, осветољубиви и да имају доминантан нагон да нанесу повреду супружнику. У складу са претходним истраживањима, ранији случајеви насиља у породици у којима су жене жртве, наводе се као најчешћи фактор смртности у овом контексту (Campbell, Glass, Sharps, Laughon \& Bloom, 2007). Упоређујући демографске карактеристике, криминалну прошлост и историју породичног насиља за 5,578 мушкараца и 1,126 жена који су ухапшени (Henning \& Feder, 2004) више мушкараца у односу на жене представљало је рецидивисте породичног нациља и насиља генерално. ${ }^{15}$

И на крају, трећи услов за изрицање ове мјере односи се на неопходност њене примјене. Она се примјењује само уколико се на други начин не може отклонити опасност од поновног извршења кривичних дјела са елементима насиља. Код ове мјере безбједности законодавац је прописао и њен начин извршења тако што је предвидио да је учинилац кривичног дјела којем је изречена ова мјера безбједности дужан да у присуству полицијског службеника одмах по правоснажности пресуде напусти стан, кућу или неки други простор који чини заједничко домаћинство са жртвом. Мјера безбједности траје од шест мјесеци до пет година, а у вријеме њеног трајања не урачунава се вријеме које је учинилац провео у казненопоправној установи или установи за лијечење (чл. 81. ст. 2). Јасно је да се ова мјера под одговарајућим условима може изрећи и уз условну осуду. Ваља истаћи да условна осуда управо и јесте најчешћа кривична санкција која се изриче извршиоцима кривичних дјела против брака и породице. Тако је у периоду 2011-2015. године од укупно изречене 961 кривичне санкције извршиоцима кривичних дјела против брака и породице, изречене 824 условне осуде $(85,74 \%) .{ }^{16}$ Управо би овдје требало да дође до изражаја изрицање мјера безбједности. Поред наведеног, законодавац је као и код претходних мјера одредио да неизвршење ове мјере представља основ за опозив условног отпуста (чл. 81 ст. 3), а усвојено је и рјешење да је лице које је удаљено из домаћинства дужно да доприноси издржавању лица која су остала у домаћинству на начин на који му то одреди суд (чл. 81. ст. 5).

\footnotetext{
${ }^{15} \mathrm{C}$ друге стране, жене насилнице наносе озбиљније повреде, имају проблема са запошљавањем и млађе су животне доби. Такође, ово истраживање је показало да су жене насилнице имале мање кривичних пријава у односу на мушкарце насилнике, а мање је вјероватно да су се њихови партнери осјећали озбиљно угрожени. Исто тако, мушкарци су имали више проблема са злоупотребом дроге и/или алкохола.

16 Вид. Статистички годишњак Републике Српске, доступно на http://www.rzs.rs.ba/front/ category/8/, приступљено 21. 08. 2018. године.
} 


\section{ЗАКљУЧАК}

Кривична дјела са предзнаком насиља представљају једну од најзначајнијих констелација криминалног понашања. Као посебно значајна питања овдје се издвајају изучавање личности починиоца ових кривичних дјела и кривичноправна реакција на извршење кривичних дјела из области насилничког криминалитета. Истраживања која су тематизирала личност извршиоца кривичног дјела са елементима насиља нису била, нити су данас ријеткост. Уочено је да је структура личности извршилаца ових кривичних дјела особена и да се у њеној основи налазе дубоко укоријењени маладаптивни обрасци који се манифестују у широком спектру односа према себи и околини.

Управо се ова ,деформисана" варијанта нормалне личности без психопатолошких садржаја својсвених ментално болесној популацији, заједно са биолошким и психолошким компонентама које се налазе и меритуму битно смањене урачунљивости, може узети као услов за изрицање мјера безбједности оријентисаних ка извршиоцима кривичних дјела са елементима насиља. Овај став ваља узети као препоруку, јер законодавац у Републици Српској као биолошке основе за (између осталог) битно смањену урачунљивост прописује само душевну болест, привремену душевну поремећеност и заосталост у душевном развоју.

Посљедњим законом о измјенама и допунама Кривичног закона Републике Српске предвиђене су мјере безбједности које се односе на извршиоце кривичних дјела са елементима насиља. Извршиоцима ових кривичних дјела се може забранити приближавање и комуникација са одређеним лицем, може им се наложити обавезан психосоцијални третман, као и удаљење из заједничког домаћинства. Услови за изрицање ових мјера безбједности нису истовјетни, што је и разумљиво. Оне су у највећој могућој мјери прилагођене личности учиниоца кривичног дјела. Значајно је да се спровођењем ових мјера безбједности отклоне стања и услови који су погодовали да се кривична дјела са елементима насиља изврше и да се извршилац кривичног дјела који више није опасан интегрише у друштво. 


\section{ЛИТЕРАТУРА}

Archer, J (2000) Sex differences in aggression between heterosexual partners. Psychological Bulletin, 126 (5), 651-680.

Bačić, F. (2009). Opći dio kaznenog prava. Zagreb: Pravni fakultet.

Bartol, C. R. \& Bartol, A. M. (2005). Criminal Behavior - A Psyhchosocial Approach. New Jersey: Pearson.

Campbell, J. C., Glass, N., Sharps, P. W., Laughon, K., \& Bloom, T. (2007). Intimate partner homicide: review and implications of research and policy. Trauma, Violence \& Abuse, 8, 246-269.

Campbell, J. C., Webster, D.W., \& Glass, N. (2009). The danger assessment: validation of a lethality risk assessment instrument for intimate partner femicide. Journal of Interpersonal Violence, 24, 653-674.

Caspi, A., Moffitt, T. E., Silva, P. A., Loeber, M. S., Krueger, R. F., \& Schmutte, P. S. (1994). Are some people crime prone? Replications of the personality crime relationship across countries, genders, races, and methods. Criminology, 32, 163-196.

Costa, P. T., \& McCrae, R. R. (1992). Revised NEO Personality Inventory (NEOPI-R) and NEO Five-Factor Inventory (NEO-FFI) Professional Manual. Odessa, FL: Psychological Assessment Resources.

Дракић, Д. (2005). Сврха мјера безбједности као кривичних санкција. Зборник радова Правног факултета у Новом Саду, 3/2005, 121 - 128.

Ellsberg M, Jansen HA, Heise L, Watts CH, Garcia-Moreno C. (2008). Intimate partner violence and women's physical and mental health in the WHO multi-country study on women's health and domestic violence: an observational study. Lancet 371 (9619), 1165-1172.

Fang X, Massetti G.M., Ouyang L., Grosse S.D., Mercy J.A. (2010). Attention-deficit/ hyperactivity disorder, conduct disorder, and young adult intimate partner violence. Archives of General Psychiatry, 67(11), 1179-1186.

Feist, J. \& Feist, G. J. (2009). Theories of Personality, seventh edition. (408-427). New York, NY: McGraw-Hill Companies.

Goldenson, J., Geffner, R., Foster, S., \& Clipson, C. (2007). Female domestic violence offenders: Their attachment security, trauma symptoms, and personality organization. Violence and Victims, 22, 530-543.

Greenfeld, L., Rand, M., Craven, D., Klaus, P., Perkins, C., Ringel, C., Warchol, G., Matson, C., and Fox, J. A. (1998). Violence by Intimates: Analysis of Data on Crimes by Current or Former Spouses, Boyfriends and Girlfriends (NCJ 167237), US Department of Justice, Bureau of Justice Statistics, Washington, DC.

Hamberger, L.K., \& Hastings, J.E. (1988). Skills training for treatment of spouse abusers: An outcome study. Journal of Family Violence, 3, 121-130.

Hamberger, L. K. \& Guse, C. E. (2002) Men's and women's use of intimate partner violence in clinical samples. Violence Against Women, 8 (11). 1301-1331. 
Hare, R.D. (2003). Hare psychopathy checklist-revised (PCL-R) (2nd ed). Toronto, Canada: Multi-Health Systems.

Healey, K., Smith, C., and O'Sullivan, C. (1998). Batterer Intervention: Program Approaches and Criminal Justice Strategies, US Department of Justice, Washington, DC.

Hemphill, J., Hare, R. \& Wong, S. (1998). Psychopathy and recidivism: A review. Legal Criminological Psychology, 3, 141-172.

Henning, K., Jones, A. \& Holdford, R.J. (2003). Treatment needs of women arrested for domestic violence: A comparison with male offenders. Journal of Interpersonal Violence, 18, 839-856.

Henning, K. \& Feder, L. (2004). A Comparison of Men and Women Arrested for Domestic Violence: Who Presents the Greater Threat? Journal of Family Violence, 19(2), 69-80.

Holtzworth-Munroe, A., and Stuart, G. (1994). Typologies of male batterers: Three subtypes and the differences among them. Psychol. Bull. 116(3), 476-497.

Игњатовић, Ђ. (2011). Појам и етиологија насилничког криминалитета. Crimen, 2, $181-212$.

John, O. P., Naumann, L. P., \& Soto, C. J. (2008). Paradigm shift to the integrative BigFive trait taxonomy: History, measurement, and conceptual issues. In O. P. John, R. W. Robins, \& L. A. Pervin (Eds.), Handbook of Personality: Theory and Research, 3rd ed. (pp. 114-158). New York, NY: Guilford Press.

Johnson, M. (1995). Patriarchal terrorism and common couple violence: Two forms of violence against women. J. Marriage Fam, 57, 283- 294.

Juodis, M., Starzomski, A., Porter, S. \& Woodworth, M. (2014). What Can be Done About High-Risk Perpetrators of Domestic Violence? Journal of Family Violence, 29, 381-390.

Ковачевић, Р. (2006). Убиство у породици. Београд: Институт за криминолошка и социолошка истраживања.Le Couff, Y., \& Toupin J. (2009). Comparing persistent juvenile delinquents and normative peers with the Five-Factor Model of personality. Journal of Research in Personality, 43, 1105-1108.

Кривични законик Републике Српске („Службени гласник PC“, број 64/17).

Le Couff, Y., \& Toupin J. (2009). Comparing persistent juvenile delinquents and normative peers with the Five-Factor Model of personality. Journal of Research in Personality, 43, 1105-1108.

Leistico, A.R., Salekin, R.T., DeCoster, J., \& Rogers, R. (2008). A large-scale metaanalysis relating the Hare measures of psychopathy to antisocial conduct. Law and Human Behavior, 32, 28-45.

Levi, M. \& Maguire, M. (2002). Violent crime. In: The Oxford Handbook of Criminology (рр. 795-843). Oxford: Oxford University Press.

Марковић, И. (2007). Основи криминлогогије. Бања Лука: Правни факултет. 
Међедовић, Ј., Кујачић, Д., Ђоковић, Н., Јеринић, М. \& Кнежевић, Г. (2011). Предикција Аморалности код осуђеника са изреченом мером обавезног лечења наркомана у Специјалној затворској болници у Београду. У: Књига резимеа са XVII научног скупа Емпиријска истраживања у психологији.(стр. 196-197). Београд: Филозофски факултет, Универзитет у Београду.

Međedović, J., Kujačić, D., \& Knežević, G. (2012). Personality-related determinants of criminal recidivism. Psihologija, 45, 277-294.

Међедовић, Ј., Кујачић, Д., и Кнежевић, Г. (2012а). Личносне диспозиције ка криминалном рецидиву у узорку институционализованих адолесцената. Зборник Института за криминолошка и социолошка истраживања, 31, 7-24.

Miller, J. D., \& Lynam, D. (2001). Structural models of personality and their relation to antisocial behavior: a meta-analytic review. Criminology, 39, 765-798.

Patrick, C.J. (Ed.). (2006). Handbook of psychopathy. New York: Guilford Press.

Rennison, C. M., and Welchans, S. (2000). Intimate Partner Violence. US Department of Justice, Office of Justice Programs, Washington, DC.

Ross, H., Gask, K., \& Berrington, A. (2011). Civil partnership five years on. Population Trends, 145(1), 172-202.

Статистички годишњак Републике Српске, доступно на http://www.rzs.rs.ba/ front/category/8/, приступљено 21. 08. 2018. године.

Stead, R. \& Fekken, G.C. (2014). Agreeableness at the Core of the Dark Triad of Personality. Individual Differential Research, 12 (4-A), (131-141).

Stuart, G.L., Moore, T.M., Gordon, K.C., Ramsey, S.E., \& Kahler, C.W. (2006). Psychopathology in women arrested for domestic violence. Journal of Interpersonal Violence, 21, 376-389.

Thornton, A. J. V., Graham-Kevan, N., \& Archer, J. (2010). Adaptive and maladaptive personality traits as predictors of violent and nonviolent offending behavior in men and women. Aggressive Behavior, 36, 177-186.

Wallace, H., Seymour, A.: „Domestic violence“; (eds) Coleman, G.; Gaboury, M.; Murray, M.; Seymour, A.; National Victim Assistence Academy; Washington, DC, U.S., Department of Justice, 2007, преузето ca https://www.ovc.gov/, приступљено 21. 06. 2018. године.

Закон о измјенама и допунама Закона о заштити од насиља у породици („Службени гласник РС“, број 108/13).

Закон о измјенама и допунама Кривичног закона Републике Српске („Службени гласник РС“, број 67/13).

Рад примљен: 04. 02. 2019.

Рад прихваћен: 29. 03. 2019. 